\title{
Evaluation of Microwave Pre-Treatment in the Spirulina Platensis Oils by Supercritical Carbon Dioxide
}

\author{
Hugo F. Lobaton', Hugo A. Martinez ${ }^{2}$ \\ ${ }^{1}$ Facultad De Ingeniería, Universitaria Agustiniana \\ Ak. 86 \#11b-95, Bogotá, Colombia \\ hugo.lobaton@uniagustiniana.edu.co \\ ${ }^{2}$ Facultad De Ingeniería, Universidad Nacional de Colombia \\ Carrera 32 \# 12-00, Palmira, Colombia \\ hamartinezco@unal.edu.co
}

\section{Extended Abstract}

Spirulina platensis is lipid-rich microalgae (0-100 $\mathrm{mg} \mathrm{g}^{-1}$ of dry biomass) among which gamma-linoleic acid, an essential fatty acid of the omega 6 family, is found. In order to consolidate the biotechnology of microalgae, it is necessary to incorporate clean technologies in the downstream processing. Extraction with supercritical carbon dioxide $\left(\mathrm{CO}_{2}\right)$ is a promising clean technology, since this generates a minimum impact to the environment because it normally operates at relatively low temperatures and generates solvent-free extracts. The literature has reported the extraction of $S$. platensis oils by means of supercritical $\mathrm{CO}_{2}$ with the help of ethanol in small quantities in order to extract the polar lipids. In addition, prior to the extraction process, it is necessary to make a cell break in order to open the cells and allow the solvent to penetrate the cell wall. The objective of this work was to examine the effective of cell lysis with microwave as pre-treatment prior to the extraction by supercritical carbon dioxide.

The extraction kinetics were modelled using the principle of open and intact cells developed by Sovová [1]. Three kinetics were developed experimentally for the same extraction conditions (Flow $20 \mathrm{~g} \mathrm{~min}^{-1}(18 \mathrm{~g} \mathrm{CO} 2+2 \mathrm{~g}$ ethanol), temperature $60^{\circ} \mathrm{C}$, pressure 360 bar and time 3 hours) but different pre-treatment conditions (microalga without pretreatment, microalga with microwave pre-treatment $420 \mathrm{~W}$ for 5 and 10 minutes). The model contains four parameters that can be estimated from the experimental data. These are the external mass transfer coefficient $(k f)$, internal mass transfer coefficient $(k s)$, percentage of opening of cells $(r)$, and the percentage of oil in the open cells $(G)$. The mathematical model was programmed in Matlab and the parameters were estimated using the minimization algorithm fminsearch adjusted the experimental data to the model.

After 3 hours of extraction, the yield with microwave pre-treatment for 5 minutes was $40 \mathrm{mg} \mathrm{g}^{-1}$ of dry biomass compared to $10 \mathrm{mg} \mathrm{g}^{-1}$ of dry biomass in the microalgae without pre-treatment. In addition, Based on the experimental results and the kinetics, it can be confirmed that microwave pre-treatment for 5 minutes truly generated cell lysis as it has a $(r=23.49 \%)$ compared to microalgae without pre-treatment $(r=3 \%)$. Finally, the estimation of parameters using the open and intact cell model helps to describe and compare the efficiency of the cell lysis process and the subsequent extraction of lipids with supercritical fluids.

\section{References}

[1] H. Sovová, "Mathematical model for supercritical fluid extraction of natural products and extraction curve evaluation," J. Supercrit. Fluids, vol. 33, no. 1, pp. 35-52, 2005. 